AGRITECH, Vol. 37, No. 2, Mei 2017, Hal. 132-138 DOI: http://doi.org/10.22146/agritech.25326 ISSN 0216-0455 (Print), ISSN 2527-3825 (Online) Tersedia online di https://jurnal.ugm.ac.id/agritech/

\title{
Pengaruh Pretreatment Secara Alkalisasi-Resistive Heating terhadap Kandungan Lignoselulosa Jerami Padi
}

\author{
The Effect of Alkalization-Resistive Heating Pretreatment on Lignocellulose Content of Rice Straw
Dewi Maya Maharani, Lisa Normalasari, Dianita Kumalasari, Chandra Ardin Hersandi Prakoso, Mutiara Kusumaningtyas, Mochamad Taufik Ramadhan

\author{
Jurusan Keteknikan Pertanian, Fakultas Teknologi Pertanian, Universitas Brawijaya, Jl. Veteran, Malang 65145, Indonesia \\ Email: maya_maharani@ub.ac.id
}

Submisi: 10 Juni 2015; Penerimaan: 8 Desember 2015

\begin{abstract}
ABSTRAK
Selulosa merupakan biomassa yang potensial digunakan untuk produksi bioetanol dan banyak ditemukan di residu pertanian seperti jerami padi. Selulosa merupakan material penting yang dapat dikonversi menjadi glukosa kemudian dikonversi menjadi bioetanol, namun selulosa pada alam dilapisi oleh ikatan lignin dan hemiselulosa menjadi lignoselulosa. Pembuatan bioetanol berbasis selulosa membutuhkan proses pretreatment yang berfungsi untuk mendegradasi ikatan lignin, meningkatkan luas permukaan biomassa dan dekristalisasi selulosa. Tujuan dari penelitian ini adalah mengetahui pengaruh alkalisasi resistive heating pada proses pretreatment jerami padi sebelum dikonversi lebih lanjut menjadi bioetanol dan mengetahui pengaruh suhu pemanasan serta konsentrasi $\mathrm{NaOH}$ selama pretreatment terhadap perubahan kandungan lignin, selulosa dan hemiselulosa. Sebelum dilakukan penelitian dilakukan perancangan reaktor resistive heating. Jerami padi ukuran 100 mesh dilarutkan pada larutan $\mathrm{NaOH}$ dengan variasi konsentrasi 0,03 $\mathrm{M}, 0,05 \mathrm{M}$, dan $0,07 \mathrm{M}$, selanjutnya dipanaskan pada reaktor resistive heating dengan variasi suhu pemanasan $75^{\circ} \mathrm{C}$, $85{ }^{\circ} \mathrm{C}$, dan $99{ }^{\circ} \mathrm{C}$. Selulosa merupakan senyawa yang akan dikonversi lebih lanjut menjadi glukosa. Sehingga pada penelitian ini dipilih kondisi optimum berdasarkan peningkatan selulosa tertinggi hingga 8,88\% serta penurunan lignin dan hemiselulosa sebesar $1,39 \%$ dan $4,33 \%$ pada perlakuan suhu pemanasan $75{ }^{\circ} \mathrm{C}$ dan konsentrasi $\mathrm{NaOH} 0,07 \mathrm{M}$. Alkalisasi resistive heating dapat diterapkan pada pretreatment jerami padi karena dapat mengurangi kandungan lignin dan hemiselulosa serta meningkatkan kandungan selulosa.
\end{abstract}

Kata kunci: Lignin; pretreatment; resistive heating; jerami

\begin{abstract}
Cellulose is a potential biomass that is used for bioethanol production and commonly present in agricultural residues like rice straw. Cellulose is an important material to produce glucose and bioethanol, but it is covered by lignin and hemicellulose bonds to form a lignocellulose. Bioethanol production using basic material containing cellulose requires special attention in the process of pretreatment for lignin degradation process and increase the accessible surface and decrystallize cellulose. The aim of this research was to apply alkalization and resistive heating combine method for rice straw pretreatment process before further being converted into bioethanol and to determine the effects of heating temperature and $\mathrm{NaOH}$ concentration on the content of lignin, cellulose, and hemicellulose. The reactor had been designed for resistive heating process. Rice straw that was resized into 100 mesh has dissolved with $0.03 \mathrm{M}, 0.05 \mathrm{M}$, and $0.07 \mathrm{M} \mathrm{NaOH}$ and heated with resistive heating temperature of $75^{\circ} \mathrm{C}, 85^{\circ} \mathrm{C}$, and $99{ }^{\circ} \mathrm{C}$. Cellulose is a raw material that will be further converted into glucose. So that, the selected optimum conditions of this study were pretreatment with the highest increase of cellulose content level until $8.88 \%$ and resulted decreasing levels of lignin (1.39\%) and
\end{abstract}


hemicellulose (4.33\%) by temperature $75^{\circ} \mathrm{C}$ and $0.07 \mathrm{M} \mathrm{NaOH}$ concentration. Resistive heating that combine with alkalization can be used for rice straw pretreatment process that reduce lignin and hemicellulose content as well as increasing cellulose content.

Keywords: Lignin; pretreatment; resistive heating; straw

\section{PENDAHULUAN}

Bioetanol merupakan bahan bakar pengganti atau campuran bensin. Bioetanol adalah etanol yang dibuat dari biomassa yang mengandung komponen pati atau selulosa. Bahan selulosa sangat potensial digunakan sebagai bahan baku bioetanol karena tidak mengancam ketahanan pangan dan umumnya merupakan residu pertanian seperti jerami padi, dimana produksi jerami padi di Indonesia pada tahun 2014 mencapai 71.279.709 ton (BPS, 2014).

Selulosa secara alami diikat oleh hemiselulosa dan lignin yang kemudian disebut lignoselulosa. Ikatan lignin dapat mengurangi efektifitas konversi bahan selulosa menjadi bioetanol. Hal tersebut dapat mengurangi produksi bioetanol. Oleh sebab itu, dilakukan proses pretreatment bahan berlignoselulosa sebelum dilakukan hidrolisis selulosa menjadi glukosa, kemudian difermentasi menjadi bioetanol. Proses pretreatment bertujuan untuk mendegradasi lignin sehingga semakin banyak selulosa yang dapat diakses dalam produksi bioetanol. Pemanasan menggunakan autoclave dan microwave merupakan beberapa bentuk pretreatment fisik yang diperlukan dalam mendegradasi lignin. Namun pemanasan tersebut masih kurang homogen terhadap bahan dan membutuhkan waktu lama. Pemanasan secara resistive atau resistive heating diterapkan untuk mempercepat penghantaran panas dan mendapatkan panas yang lebih homogen. Resistive heating adalah pemanasan bahan dengan cara melewatkan bahan pada aliran listrik. Pada resistive heating, bahan yang dilewati arus listrik memberi respon berupa pembangkitan panas secara internal akibat adanya tahanan listrik dalam bahan tersebut (Sastry, 2008). Penerapan resitive heating memiliki kelebihan dibandingkan metode pemanasan lainnya yaitu pemanasannya seragam dan lebih cepat, bersih dan lebih ramah lingkungan serta energi yang dibutuhkan lebih efisien (Castro dkk., 2004). Sejauh ini metode resistive heating hanya digunakan sebatas pada bahan pertanian (makanan) dan belum diketahui pengaruhnya terhadap pretreatment lignoselulosa. Oleh karena itu, pada penelitian ini dilakukan pretreatment selulosa jerami padi menggunakan resistive heating yang dikombinasikan dengan alkalisasi.

Tujuan penelitian ini adalah mengetahui pengaruh suhu pemanasan dan pemberian konsentrasi $\mathrm{NaOH}$ pada proses pretreatment terhadap kandungan lignin, hemiselulosa, dan selulosa jerami padi serta memperoleh kondisi optimum dari variasi yang dilakukan pada penelitian ini. Penelitian ini dilakukan untuk mengetahui pengaruh resistive heating yang dikombinasikan dengan alkalisasi terhadap perubahan kandungan lignoselulosa jerami padi dan pengaruhya terhadap efektifitas proses pretreatment jerami padi untuk produksi bioetanol.

\section{METODE PENELITIAN}

\section{Alat dan Bahan}

Alat yang digunakan pada penelitian ini adalah reaktor resistive heating seperti yang terlihat pada Gambar 1 dan terdiri dari tabung reaktor dengan dimensi panjang $23 \mathrm{~cm}$, kedua ujung reaktor dipasang elektroda stainless stell dengan diameter $8 \mathrm{~cm}$, kabel konektor, thermocouple tipe $\mathrm{K}$, thermocontrol display merek OMRON serta pengukur arus clamp meter. Bahan yang digunakan dalam penelitian ini berupa bubuk jerami padi varietas Ciherang yang telah digiling dan diayak hingga ukuran 100 mesh serta larutan kimia berupa $\mathrm{NaOH}$ dan akuades yang didapatkan dari $\mathrm{CV}$. Sumber Makmur Malang.

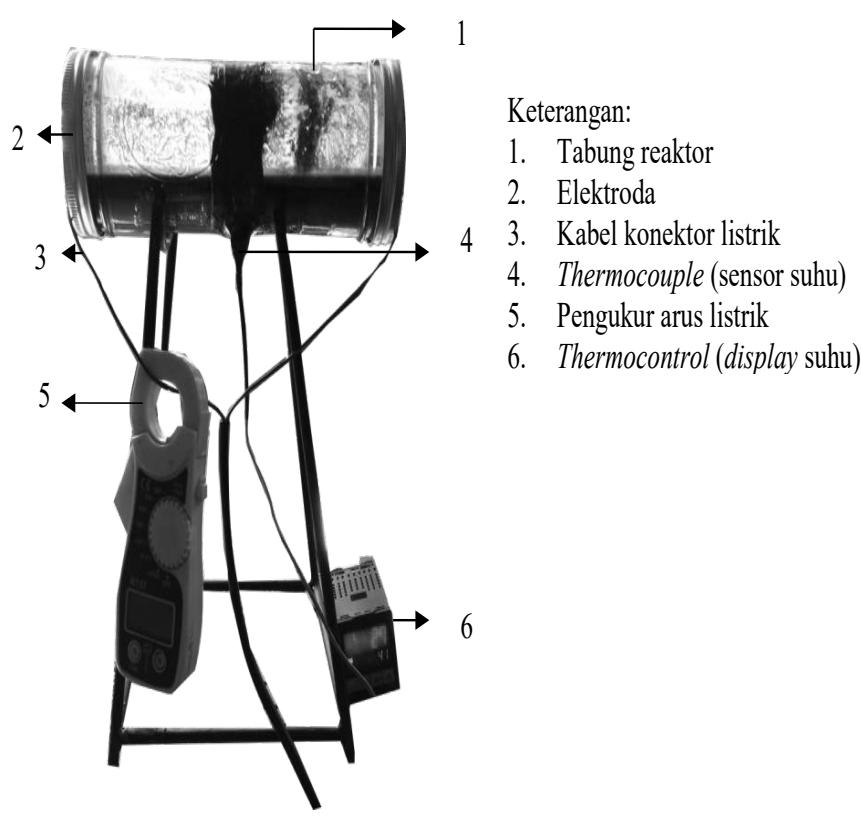

Gambar 1. Reaktor resistive heating beserta komponennya 
Tabel 1. Rancangan penelitian pretreatment degradasi lignin jerami padi menggunakan alkalisasi resistive heating

\begin{tabular}{cccc}
\hline \multirow{2}{*}{$\begin{array}{c}\text { Konsentrasi } \\
\text { NaOH (M) }\end{array}$} & \multicolumn{3}{c}{ Suhu (T) } \\
\cline { 2 - 4 } & $\mathrm{T} 1=75{ }^{\circ} \mathrm{C}$ & $\mathrm{T} 2=85^{\circ} \mathrm{C}$ & $\mathrm{T} 3=99^{\circ} \mathrm{C}$ \\
\hline $\mathrm{M} 1=0,03 \mathrm{M}$ & $\mathrm{M}_{1} \mathrm{~T}_{1}$ & $\mathrm{M}_{1} \mathrm{~T}_{2}$ & $\mathrm{M}_{1} \mathrm{~T}_{3}$ \\
$\mathrm{M} 2=0,05 \mathrm{M}$ & $\mathrm{M}_{2} \mathrm{~T}_{1}$ & $\mathrm{M}_{2} \mathrm{~T}_{2}$ & $\mathrm{M}_{2} \mathrm{~T}_{3}$ \\
$\mathrm{M} 3=0,07 \mathrm{M}$ & $\mathrm{M}_{3} \mathrm{~T}_{1}$ & $\mathrm{M}_{3} \mathrm{~T}_{2}$ & $\mathrm{M}_{3} \mathrm{~T}_{3}$ \\
\hline
\end{tabular}

\section{Rancangan Penelitian}

Rancangan penelitian yang digunakan pada penelitian ini adalah Rancangan Acak Lengkap (RAL) yang tersusun atas 2 faktor yaitu besarnya suhu (T) yang diberikan selama pemanasan serta konsentrasi $\mathrm{NaOH}(\mathrm{M})$. Faktor bebas suhu pemanasan terdiri dari 3 level variasi suhu $75^{\circ} \mathrm{C}, 85^{\circ} \mathrm{C}$, dan $99^{\circ} \mathrm{C}$ sedangkan faktor bebas konsentrasi $\mathrm{NaOH}$ terdiri dari 3 level variasi konsentrasi $\mathrm{NaOH}$ 0,03 M, 0,05 M, dan 0,07 M. Berdasarkan kedua faktor tersebut maka didapatkan 9 variasi perlakuan seperti yang ditampilkan pada Tabel 1 .

\section{Pretreatment Lignoselulosa Jerami Padi dan Analisis Data}

Penelitian dilakukan dengan tahapan yang ditunjukkan pada Gambar 2. Sampel berupa bubuk jerami padi varietas Ciherang berukuran 100 mesh sebanyak 30 g dicampurkan dengan larutan $\mathrm{NaOH}$ dengan konsentrasi sesuai pada

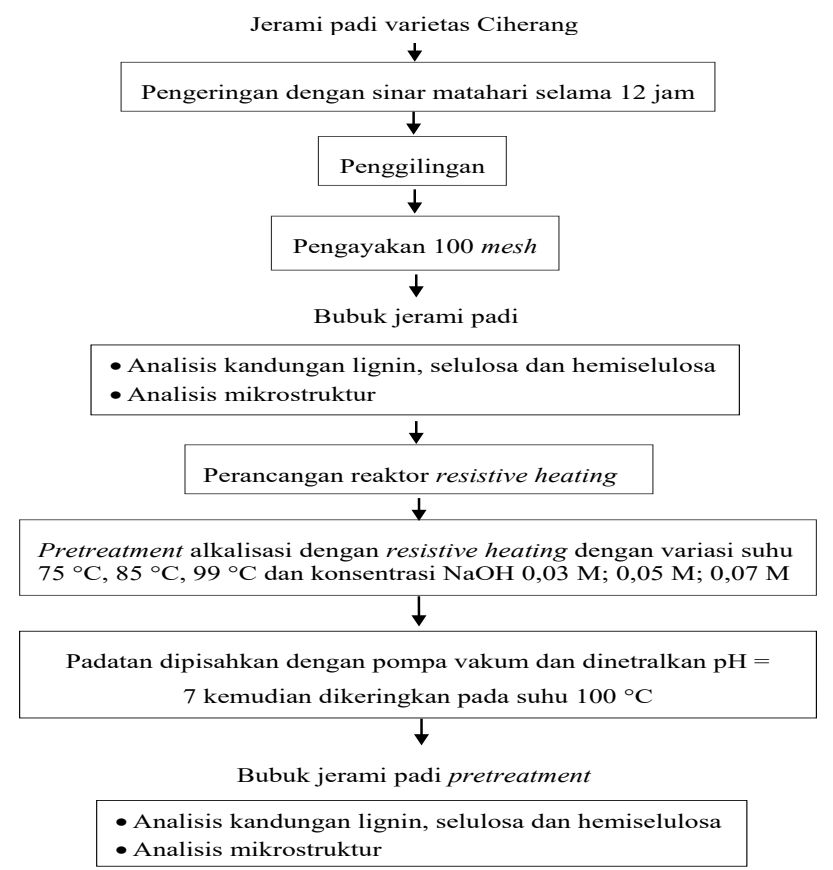

Gambar 2. Diagram alir penelitian pengaruh variasi suhu pemanasan dan konsentrasi $\mathrm{NaOH}$ pada pretreatment degradasi lignin rancangan penelitian dengan perbandingan 1:10 dan diletakkan dalam reaktor resistive heating. Sampel berupa campuran bubuk jerami padi dan larutan $\mathrm{NaOH}$ dalam reaktor kemudian dialirkan listrik dengan tegangan $220 \mathrm{~V}$ dari kedua elektroda pada ujung reaktor hingga mencapai suhu pemanasan yang telah ditentukan. Selanjutnya bubuk jerami padi setelah pretreatment dipisahkan dari larutan $\mathrm{NaOH}$ dan dinetralkan kemudian dikeringkan dalam oven selama 3 jam pada suhu $105^{\circ} \mathrm{C}$.

Sampel sebelum dan setelah pretreatment kemudian diuji kandungan lignin, selulosa, dan hemiselulosa dengan menggunakan metode Chesson sesuai Datta (1981) dalam Dehani dkk. (2013). Sampel setelah pretreatment dengan hasil perlakuan terbaik dianalisis mikrostruktur dengan SEM (Scanning Electron Microscopy) dan dibandingkan dengan mikrostruktur sampel sebelum proses pretreatment.

\section{HASIL DAN PEMBAHASAN}

\section{Pengaruh Pretreatment Alkalisasi Resistive Heating terhadap Kandungan Lignin Jerami Padi}

Pengaruh suhu pemanasan dan konsentrasi $\mathrm{NaOH}$ terhadap kandungan lignin jerami padi terdapat pada Gambar 3. Kandungan lignin jerami padi sebelum pretreatment adalah $11,12 \%$. Pada konsentrasi $\mathrm{NaOH} \mathrm{0,07} \mathrm{M,} \mathrm{kandungan}$ lignin jerami padi berkurang menjadi $9,73 \%$ pada suhu 75 ${ }^{\circ} \mathrm{C}$, sedangkan pada suhu $85{ }^{\circ} \mathrm{C}$ dan $99{ }^{\circ} \mathrm{C}$ berturut-turut menjadi $9,50 \%$ dan $7,05 \%$. Semakin tinggi suhu pemanasan yang digunakan, kandungan lignin jerami padi semakin kecil. Semakin tinggi suhu pemanasan maka semakin lama waktu pretreatment yang digunakan, pada suhu $99^{\circ} \mathrm{C}$ lama pretreatment adalah 3,9 menit sedangkan waktu pretreatment pada suhu $75^{\circ} \mathrm{C}$ dan $85^{\circ} \mathrm{C}$ adalah 3,25 menit dan 3,4 menit. Lama waktu bahan kontak dengan panas maupun dengan

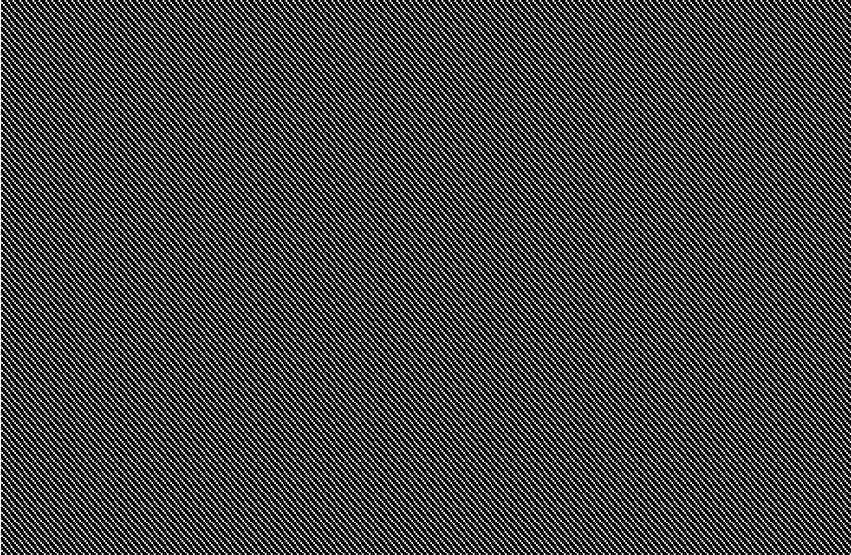

Gambar 3. Kandungan lignin jerami padi pada variasi suhu pemanasan dan konsentrasi $\mathrm{NaOH}$ 
larutan alkali, menyebabkan senyawa yang terlepas dari dinding sel semakin banyak (Ni'mah dkk., 2014).

Pada Gambar 3, kandungan lignin jerami padi pada suhu pemanasan $75^{\circ} \mathrm{C}, 85^{\circ} \mathrm{C}$, dan $99{ }^{\circ} \mathrm{C}$ semakin rendah dengan adanya penambahan konsentrasi $\mathrm{NaOH}$ dari $0,03 \mathrm{M}, 0,05$ M, dan 0,07 M. Hal ini dapat dilihat pada perlakuan dengan menggunakan suhu $99^{\circ} \mathrm{C}$, kandungan lignin pada konsentrasi $\mathrm{NaOH} 0,03 \mathrm{M}$ selama pretreatment adalah 10,78\% dan pada konsentrasi $\mathrm{NaOH} 0,05 \mathrm{M}$ serta $0,07 \mathrm{M}$ secara berurutan kandungan lignin menjadi lebih rendah yaitu 9,19\% dan 7,05\%. Semakin besar penggunaan konsentrasi $\mathrm{NaOH}$ penurunan kandungan lignin jerami padi semakin besar.

Penambahan $\mathrm{NaOH}$ pada proses pretreatment jerami padi dapat menurunkan kandungan lignin yang cukup besar hingga 4,64\%, karena reaksi pemutusan ikatan lignin menjadi lebih cepat (Dehani dkk., 2013). Berdasarkan peningkatan konsentrasi $\mathrm{NaOH}$ berarti meningkatkan jumlah ion hidroksil di dalam cairan. Ion-ion hidroksil ini akan memutuskan ikatan-ikatan dari struktur dasar pembentuk lignin, sehingga lignin menjadi lebih mudah untuk dilarutkan (Jalaluddin dan Rizal, 2005). Peningkatan suhu pemanasan hingga 99 ${ }^{\circ} \mathrm{C}$ dengan konsentrasi $\mathrm{NaOH}$ 0,07 $\mathrm{M}$ merupakan perlakuan yang menghasilkan kandungan lignin paling rendah dalam penelitian ini.

\section{Pengaruh Pretreatment Alkalisasi Resistive Heating terhadap Kandungan Selulosa Jerami Padi}

Hasil pengujian kandungan selulosa pada variasi suhu pemanasan dan konsentrasi $\mathrm{NaOH}$ dapat dilihat pada Gambar 4. Kandungan selulosa jerami padi sebelum pretreatment adalah $27,09 \%$. Pada pretreatment dengan suhu $75^{\circ} \mathrm{C}$, terjadi peningkatan selulosa seiring dengan penambahan konsentrasi $\mathrm{NaOH}$. Pada konsentrasi NaOH 0,03 M, 0,05 M, dan 0,07 M, kandungan selulosa jerami padi secara berturut-turut adalah

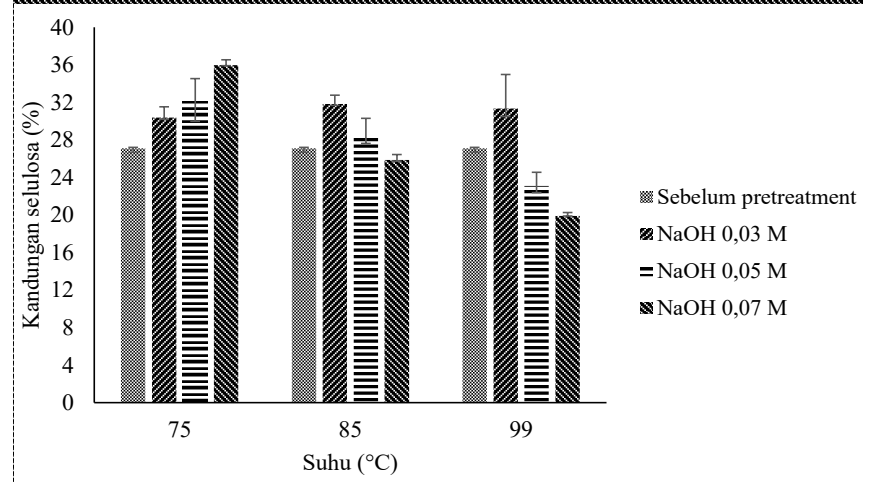

Gambar 4. Kandungan selulosa jerami padi pada variasi suhu dan konsentrasi $\mathrm{NaOH}$
30,38\%, 32,11\%, dan 35,97\%. Peningkatan selulosa tertinggi pada konsentrasi $\mathrm{NaOH} 0,07 \mathrm{M}$ yaitu $8,88 \%$. Namun pada penggunaan suhu yang lebih tinggi yaitu $85{ }^{\circ} \mathrm{C}$ dan $99{ }^{\circ} \mathrm{C}$, kandungan selulosa cenderung semakin kecil seiring dengan penambahan konsentrasi $\mathrm{NaOH}$. Pada pretreatment suhu $85^{\circ} \mathrm{C}$ kandungan selulosa dengan konsentrasi $\mathrm{NaOH} 0,03 \mathrm{M}, 0,05$ $\mathrm{M}$, dan 0,07 M secara berturut-turut adalah 31,83\%, 28,30\%, dan $25,86 \%$. Penurunan kandungan selulosa semakin besar pada pretreatment $99{ }^{\circ} \mathrm{C}$ seperti pada grafik di Gambar 4 .

Berdasarkan data tersebut pada suhu pemanasan $75^{\circ} \mathrm{C}$ menunjukkan bahwa semakin besar konsentrasi $\mathrm{NaOH}$ maka semakin besar kandungan selulosa jerami padi. Sedangkan pada suhu pemanasan $85^{\circ} \mathrm{C}$ dan $99^{\circ} \mathrm{C}$ menunjukkan bahwa semakin besar konsentrasi $\mathrm{NaOH}$ maka semakin kecil kandungan selulosa jerami padi. Penambahan konsentrasi $\mathrm{NaOH}$ dapat menyebabkan selulosa ikut terdegradasi jika suhu pemanasan $85{ }^{\circ} \mathrm{C}$ dan $99{ }^{\circ} \mathrm{C}$. Pada konsentrasi $\mathrm{NaOH}$ yang sama, semakin besar suhu pemanasan memiliki kecenderungan kandungan selulosa semakin kecil. Hal ini sesuai dengan Gaol dkk. (2013) yang menyatakan bahwa penggunaan suhu tinggi dapat menyebabkan selulosa ikut terdegradasi sehingga yield produk turun.

Peningkatan konsentrasi $\mathrm{NaOH}$ sebesar 0,07 $\mathrm{M}$ dengan suhu pemanasan $75^{\circ} \mathrm{C}$ didapatkan nilai kandungan selulosa paling tinggi dalam penelitian ini yaitu $35,97 \%$. Hal ini dikarenakan resistive heating telah bekerja ke dalam bahan dengan melewatkan arus listrik dalam bahan sehingga timbul panas internal dalam bahan. Aliran listrik menyebabkan peningkatan suhu yang cepat secara internal pada reaktan, solven, dan produk. Resistive heating pada cairan mengubah energi listrik menjadi panas secara internal. Efek panas berasal dari bahan yang menjadi tahanan/hambatan listrik ketika dialiri arus listrik. Selain itu efek panas juga ditimbulkan oleh adanya vibrasi yang terjadi antar partikel jerami padi sehingga semakin mempercepat laju reaksi antara partikel bubuk jerami padi dan larutan $\mathrm{NaOH}$.

Proses interaksi panas dari aliran listrik dengan bahan mengakibatkan kandungan hemiselulosa yang mengikat selulosa dapat terurai dan kandungan lignin sebagai lapisan terluar yang menghalangi selulosa mulai turun. Panas yang ditimbulkan oleh resistive heating berasal dari vibrasi sel yang menyebabkan terjadinya friksi dan disipasi dalam bentuk panas yang dapat meningkatkan laju difusi alkali (Rahma, 2012). Peningkatan laju difusi akan membantu mempercepat laju difusi alkali ke dalam sel-sel sehingga proses penguraian lignin dan hemiselusosa semakin cepat dan reaksi dapat ditingkatkan serta waktu proses dapat diturunkan. Oleh karena itu, pretreatment alkalisasi resistive heating mampu memberikan nilai kandungan selulosa yang lebih tinggi daripada kandungan selulosa sebelum pretreatment alkalisasi resistive heating. 


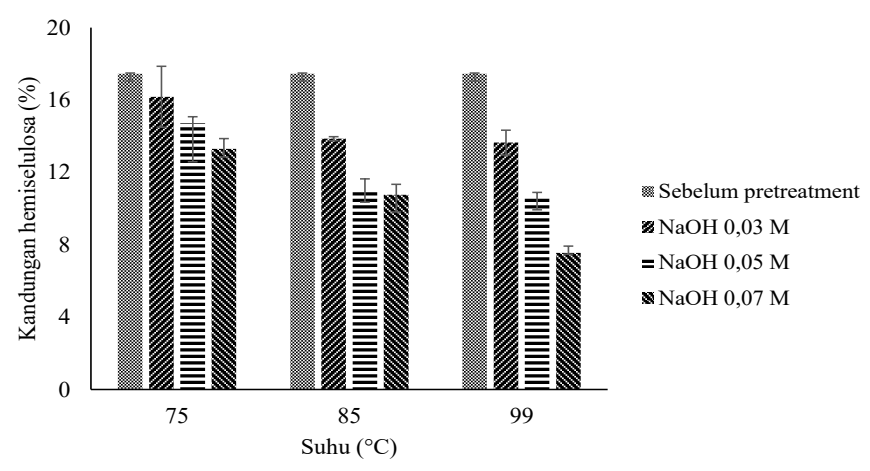

Gambar 5. Kandungan hemiselulosa jerami padi pada variasi suhu pemanasan dan konsentrasi $\mathrm{NaOH}$

\section{Pengaruh Pretreatment Alkalisasi Resistive Heating terhadap Kandungan Hemiselulosa Jerami Padi}

Pengaruh perlakuan suhu pemanasan dan konsentrasi $\mathrm{NaOH}$ terhadap kandungan hemiselulosa jerami padi terdapat pada Gambar 5. Pada Gambar 5 terlihat bahwa kandungan hemiselulosajerami padi sebelum pretreatment adalah $17,46 \%$. Pretreatment alkalisasi resistive heating menyebabkan pengurangan hemiselulosa jerami padi. Pada pretreatment suhu $75{ }^{\circ} \mathrm{C}, 85{ }^{\circ} \mathrm{C}$, dan $99{ }^{\circ} \mathrm{C}$ menunjukkan pengurangan hemiselulosa ketika diberi perlakuan peningkatan konsentrasi $\mathrm{NaOH}$ 0,03 M, 0,05 M, dan 0,07 M. Pada pretreatment suhu $99{ }^{\circ} \mathrm{C}$ dengan konsentrasi $\mathrm{NaOH} 0,03 \mathrm{M}, 0,05 \mathrm{M}$, dan 0,07 $\mathrm{M}$ dihasilkan hemiselulosa secara berturut-turut sebesar $13,89 \%, 10,73 \%$, dan 7,58\%. Berdasarkan data tersebut juga didapatkan bahwa semakin besar konsentrasi $\mathrm{NaOH}$ maka semakin kecil kandungan hemiselulosa.

Semakin besar suhu pemanasan maka kandungan hemiselulosa cenderung semakin kecil. Hal ini dapat dilihat pada konsentrasi $\mathrm{NaOH} 0,07 \mathrm{M}$ dengan suhu pretreatment
$75{ }^{\circ} \mathrm{C}, 85{ }^{\circ} \mathrm{C}$, dan $99{ }^{\circ} \mathrm{C}$ secara berturut-turut kandungan selulosa menjadi $13,14 \%, 10,43 \%$, dan $7,58 \%$. Hemiselulosa merupakan golongan zat karbohidrat yang tidak larut dalam air mendidih, tetapi larut dalam alkali encer dan hancur dalam asam encer (Anggoridi, 1979 dalam Dehani dkk., 2013).

\section{Perlakuan Optimum dalam Penelitian}

Pretreatment kombinasi alkalisasi dan resistive heating pada penelitian ini menghasilkan penurunan kandungan lignin terbesar hingga $4,08 \%$ dan penurunan hemiselulosa hingga 9,89\% pada perlakuan suhu $99{ }^{\circ} \mathrm{C}$ dan konsentrasi $\mathrm{NaOH}$ $0,07 \mathrm{M}$. Pengaruh pretreatment alkalisasi resistive heating terhadap kandungan selulosa pada pemberian suhu terendah $75{ }^{\circ} \mathrm{C}$ mengakibatkan kandungan selulosa terus meningkat seiring peningkatan konsentrasi $\mathrm{NaOH}$ yaitu pada konsentrasi $\mathrm{NaOH}$ tertinggi $0,07 \mathrm{M}$ dihasilkan peningkatan selulosa terbesar $8,88 \%$. Namun pada suhu yang lebih tinggi terjadi penurunan selulosa seiring peningkatan konsentrasi $\mathrm{NaOH}$. Berdasarkan Maurya dkk. (2015) pretreatment bertujuan untuk meningkatkan akses dan luas permukaan selulosa serta mendegradasi ikatan lignin dan hemiselulosa yang melapisi selulosa. Pada proses pembuatan bioetanol, fraksi selulosa merupakan bagian yang dikonversi lebih lanjut menjadi glukosa untuk kemudian menjadi bioetanol (Mosier dkk., 2005). Oleh karena itu, hasil penelitian yang dipilih sebagai hasil yang optimum adalah pretreatment yang menghasilkan peningkatan selulosa tertinggi yaitu pada perlakuan suhu pemanasan $75^{\circ} \mathrm{C}$ dan konsentrasi $\mathrm{NaOH}$ 0,07 M. Pada variasi perlakuan tersebut dihasilkan pengurangan lignin sebesar $1,39 \%$ dan pengurangan hemiselulosa sebesar $4,33 \%$.

\section{Analisis Kebutuhan Energi, Biaya, dan Bahan Kimia}

Kebutuhan energi adalah hal yang perlu dianalisis dalam suatu proses mengingat produksi bioetanol nantinya

Tabel 2. Perbandingan kebutuhan energi, biaya, dan zat kimia pada pretreatment dengan autoclave, microwave, dan resistive heating

\begin{tabular}{|c|c|c|c|}
\hline & Autoclave & Microwave & Resistive Heating PLN (2015) \\
\hline & Rokhmah (2011) & Dehani dkk. (2013) & \\
\hline \multirow[t]{3}{*}{ Spesifikasi alat } & Tekanan $304,5 \mathrm{kPa}$ & Panasonic GD 971 & Kuat arus $0,2 \mathrm{~A}$ \\
\hline & Tegangan $220 \mathrm{~V}$ & Frek $2450 \mathrm{MHz}$ & Tegangan $220 \mathrm{~V}$ \\
\hline & & Tegangan $220 \mathrm{~V}$ & \\
\hline Daya (Watt) & 1500 & 950 & 44 \\
\hline Waktu (menit) & 60 & 40 & 6 \\
\hline Energi (kWh) & 1,5 & 0,633 & 0,0044 \\
\hline Biaya $(\operatorname{Rp} 1.352,-/ \mathrm{kWh}) * * *$ & 2.028 & 856,27 & 5,95 \\
\hline Konsentrasi $\mathrm{NaOH}(\mathrm{M})$ & 0,5 & 0,5 & 0,07 \\
\hline Suhu pemanasan $\left({ }^{\circ} \mathrm{C}\right)$ & 107 & 89 & 75 \\
\hline
\end{tabular}


Tabel 3. Perbandingan persentase penurunan dan peningkatan lignin, hemiselulosa, dan selulosa pada beberapa alat pretreatment

\begin{tabular}{lccr}
\hline & $\begin{array}{c}\text { Autoclave } \\
\text { (Rokhmah, 2011) }\end{array}$ & $\begin{array}{c}\text { Microwave-NaOH pretreatment } \\
\text { (Singh dkk., 2014) }\end{array}$ & $\begin{array}{c}\text { Alkalisasi resistive } \\
\text { heating }\end{array}$ \\
\hline Penurunan lignin & $5,86 \%$ & $12,10 \%$ & $1,39 \%$, maksimum $4,08 \%$ \\
Penurunan hemiselulosa & $17,61 \%$ & $7,44 \%$ & $4,32 \%$, maksimum $9,89 \%$ \\
Peningkatan selulosa & turun $2,7 \%$ & turun $1,46 \%$ & meningkat $8,88 \%$ \\
\hline
\end{tabular}

akan dilakukan dalam skala yang besar. Pada pretreatment alkalisasi resistive heating dilakukan analisis kebutuhan energi yang mencakup kebutuhan energi listrik selama proses pretreatment dengan alkalisasi resistive heating. Kebutuhan energi, biaya dan bahan kimia yang digunakan pada pretreatment alkalisasi resistive heating dan perbandingannya dengan metode pretreatment terdahulu dapat dilihat pada Tabel 2. Waktu pretreatment dengan alkalisasi resitive heating jauh lebih cepat dibandingkan dengan metode autoclave dan microwave. Waktu pemanasan yang lebih cepat menyebabkan konsumsi energi dan biaya operasional untuk proses pretreatment dengan alkalisasi resistive heating lebih rendah dibandingkan dengan metode autoclave dan microwave. Pretreatment menggunakan alkalisasi resistive heating dalam penelitian ini membutuhkan konsentrasi bahan kimia $\mathrm{NaOH}$ yang jauh lebih rendah yaitu $0,07 \mathrm{M}$ dibandingkan dengan autoclave dan microwave yang menggunakan konsentrasi $\mathrm{NaOH}$ 0,5 M. Suhu pemanasan pada pretreatment alkalisasi resistive heating yang menghasilkan peningkatan selulosa paling tinggi pada penelitian ini adalah $75^{\circ} \mathrm{C}$. Suhu pemanasan tersebut juga jauh lebih rendah dibandingkan pemanasan dengan autoclave dan microwave.

\section{Analisis Mikrostruktur}

Pengujian mikrostruktur jerami padi sebelum dan setelah pretreatment dilakukan dengan metode SEM (Scanning Electron Microscopy). Gambar 6 menunjukkan perbedaan penampakan mikrostruktur bubuk jerami padi sebelum (a) dan setelah (b) dilakukan pretreatment menggunakan alkalisasi resistive heating. Pada pembesaran 500x, bubuk jerami padi

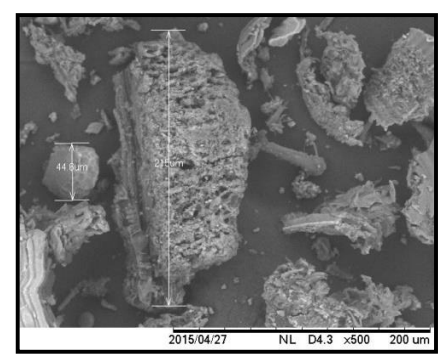

(a)

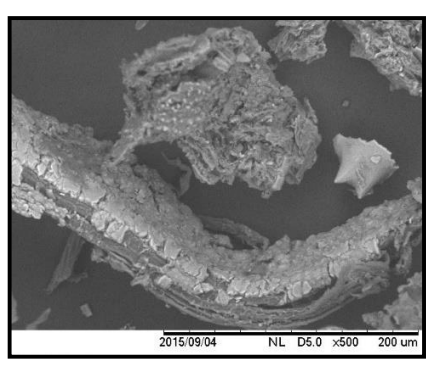

(b)
Gambar6. Hasil SEM jerami dengan pembesaran 500x (a) sebelum pretreatment (b) setelah pretreatment sebelum pretreatment berbentuk bongkahan kompak dengan rongga-rongga kecil yang menandakan belum terdegradasinya kandungan lignin. Penampakan mikrostruktur bubuk jerami padi yang telah dilakukan pretreatment memiliki ronggarongga lebih banyak dan berukuran lebih besar daripada sebelum dilakukan pretreatment. Hal ini disebabkan ikatan lignin telah terurai dan mampu memecah karbohidrat pada jerami padi yang didalamnya terkandung selulosa dan hemiselulosa. Luas permukaan bongkahan semakin besar menandakan semakin besarnya luas permukaan biomassa. Peningkatan luas permukaan biomassa menyebabkan kontak enzim terhadap selulosa pada proses hidrolisis akan semakin mudah dan meningkatkan glukosa yang terkonversi dari selulosa.

\section{Perbandingan dengan Alat Pretreatment Lain}

Perbandingan perubahan kandungan lignin, selulosa, dan hemiselulosa dengan penelitian yang menggunakan alat pretreatment lain yaitu autoclave Rokhmah (2011) dan microwave Singh dkk. (2014) dapat dilihat pada Tabel 3. Persentase penurunan lignin dan hemiselulosa pada metode alkalisasi-resistive heating lebih rendah dibandingkan metode autoclave maupun microwave. Namun, peningkatan selulosa pada pretreatment dengan metode alkalisasi resistive heating lebih tinggi dibandingkan metode autoclave dan microwave. Semakin besar kandungan selulosa maka semakin besar pula glukosa yang akan dikonversi menjadi bioetanol.

\section{KESIMPULAN}

Perlakuan dengan peningkatan selulosa terbesar dalam penelitian ini adalah pretreatment dengan suhu $75{ }^{\circ} \mathrm{C}$ dan konsentrasi $\mathrm{NaOH}$ 0,07 $\mathrm{M}$ sebesar 8,88\%. Peningkatan selulosa terjadi karena ada kandungan lignin yang berkurang yaitu sebesar 1,39\% dan pengurangan hemiselulosa sebesar 4,33\%. Penerapan pretreatment alkalisasi resistive heating pada bahan selulosa seperti jerami padi memiliki kelebihan antara lain rendahnya kebutuhan energi, biaya operasional serta bahan kimia dibandingkan dengan pretreatment menggunakan autoclave dan microwave. 


\section{DAFTAR PUSTAKA}

BPS. (2014). Tabel luas panen-produktivitas-produksi tanaman padi seluruh provinsi. http://www.bps.go.id/ Subjek/view/id/53\#subjekViewTab3. [25 September 2014].

Castro, A., Teixeira, J.A., Salengke, S., Sastry, S.K. dan Vicente, A.A. (2004). Ohmic heating of strawberry products: electrical conductivity measurements and ascorbic acid degradation kinetics. Innovative Food Science Emerging Technologies 5(1): 27-36.

Dehani, F.R., Argo, B.D. dan Yulianingsih, R. (2013). Pemanfaatan iradiasi gelombang mikro untuk memaksimalkan proses pretreatment degradasi lignin jerami padi (pada produksi bioetanol). Jurnal Bioproses Komoditas Tropis 1(1): 13-20.

Gaol, M.R.L., Sitorus, R., Yanthi, S., Surya, I., Manurung, R. (2013). Pembuatan selulosa asetat dari $\alpha$-selulosa tandan kosong kelapa sawit. Jurnal Teknik Kimia USU 2(3): 33-39.

Jalaluddin dan Rizal, S. (2005). Pembuatan pulp dari jerami padi menggunakan natrium hidroksida. Jurnal Sistem Teknik Industri 6(5): 53-56.

Maurya, D.P., Singla, A. dan Negi, S. (2015). An overview of key pretreatment process for biological conversion of lignocellulosic biomass to bioethanol. Biotech 5(3): 1-13.
Mosier, N., Wyman, C., Dale, B., Elander, R., Lee, Y.Y., Holtzapple, M. dan Ladisch, M. (2005). Features of promising technologies for pretreatment of lignocellulosic biomass. Bioresource Technology 96(6): 673-686

Ni'mah, F., Argo, D.B., Lutfi, M., Maharani, D.M. dan Putranto, A.W. (2014). Perbandingan proses pretreatment degradasi lignin jerami padi dengan wet milling dan dry milling pada produksi bioetanol. Jurnal Teknologi Pertanian 15(2): 77-84.

PLN. (2015). Tarif listrik Juni 2015. http://www.pln.go.id diakses pada 26 Agustus 2015 pukul 22.52.

Rahma, R.N.S. (2012). Studi Pengaruh Lama Pemanasan dan Konsentrasi Koh Selama Pemanasan Ohmic terhadap Laju Pengeringan dan Rendemen SRC (Semi Refined Carrageenan). Skripsi. Fakultas Pertanian. Universitas Hasanuddin, Makassar.

Rokhmah, I. (2011). Pengaruh Pretreatment (Delignifikai) Bertekanan terhadap Kandungan Bubuk Jerami Padi Giling pada Produksi Bioetanol. Skripsi. Jurusan Keteknikan Pertanian. Universitas Brawijaya, Malang.

Sastry, S. (2008). Ohmic heating and moderate electric field processing. Journal Food Science and Technology International 14(5): 419.

Singh, R., Tiwari, S., Srivastava, M. dan Shukla, A. (2014). Microwave assisted alkali pretreatment if rice straw for enchancing enzymatic digesbility. Journal of Energy 2014: $1-7$. 